\title{
Chronic Myelomonocytic Leukemia with Eosinophilia Associated with $\mathrm{t}(5 ; 12)$ (q31;p12)
}

National Cancer Institute

\section{Source}

National Cancer Institute. Chronic Myelomonocytic Leukemia with Eosinophilia Associated with t(5;12)(q31;012). NCI Thesaurus. Code C129852.

Chronic myelomonocytic leukemia characterized by the presence of eosinophilia, PDGFRB gene rearrangement, and $t(5 ; 12)(q 31 ; p 12)$. 